\title{
ALOJAMENTOS DE TRABALHADORES MIGRANTES EM USINAS DE CANA DE AÇÚCAR: ESPAÇO SOCIAL DE DOMINAÇÃO E RESISTÊNCIA.
}

\author{
Marilda Aparecida de Menezes ${ }^{1}$ \\ Maciel Cover ${ }^{2}$
}

\section{Introdução}

O setor do agronegócio canavieiro tem sido destaque na pauta das discussões brasileiras nos últimos anos. Do ponto de vista econômico, o destaque é para as cifras: o Brasil é o maior produtor mundial de cana-de-açúcar; o maior estado produtor é São Paulo, que contem 55,3\% da área total deste cultivo no país. Nas últimas duas décadas, a produtividade dos trabalhadores aumentou consideravelmente, mas o padrão de salários se manteve o mesmo. Vários pesquisadores, tais como Alves (2007), Silva (2008), Novaes (2009), Guanais (2011), têm refletido sobre diversos conflitos nas relações de trabalho. Identifica-se que a aceleração no ritmo do trabalho provoca um aumento de problemas de saúde, mortes por exaustão física e diminuição do tempo de vida útil do trabalhador. Ao mesmo tempo percebem-se reações dos trabalhadores, seja através de ações públicas, como os "paradeiros" (Candido, 2011) ou de ações dissimuladas (Silva, 2011). Neste artigo buscaremos demonstrar que as relações de exploração/dominação e resistência também estão presentes nos espaços de moradia de trabalhadores migrantes. Descreveremos as relações de sociabilidade nos alojamentos, observando as hierarquias estabelecidas no processo de trabalho e os códigos de conduta que informam uma sabedoria própria para realizar a vida cotidiana.

$\mathrm{O}$ artigo fundamenta-se em etnografia e entrevistas realizadas em um alojamento de trabalhadores migrantes, provenientes da região do Sertão de Cajazeiras, Estado da Paraíba, e que trabalham na Usina Peperoni na região de Piracicaba/São Paulo. No ano de 2010, no mês de fevereiro, realizamos uma visita de campo na localidade de origem destes trabalhadores migrantes, no município de São José de Piranhas/PB. Em maio e em outubro de 2010, um dos autores, Maciel Cover, fez o trabalho de observação participante convivendo nestas duas inserções com os trabalhadores num alojamento. Foi possível conviver durante 10 dias no mês de maio e durante 24 dias no mês de outubro. A observação participante era registrada diariamente e a cada dois dias Maciel enviava por e-mail os diários de campo para Marilda que fazia comentários. Este

\footnotetext{
${ }^{1}$ Universidade Federal de Campina Grande, Brasil.

${ }^{2}$ Universidade Federal de Campina Grande, Brasil.
} 
diálogo digital permitia que o pesquisador participante incorporasse também elementos da pesquisadora distante que acompanhava via e-mail. Essa interlocução foi bastante proveitosa.

O artigo está organizado em quatro partes. A primeira trata de reflexões sobre o trabalho de campo; a segunda sobre a contratação de trabalhadores migrantes na Usina Peperoni; a terceira sobre os alojamentos como espaços de controle da força de trabalho e a quarta parte sobre os códigos de conduta e a sabedoria para viver em "barracos".

\section{Reflexões sobre trabalho de campo}

A entrada em campo é uma experiência importante para compreender como se constroem as interações sociais entre os (as) pesquisadores (as) e os sujeitos da pesquisa. Nosso acesso aos trabalhadores migrantes e aos funcionários da usina que estão em diferentes posições hierárquicas foi mediado por dois atores sociais: o Sindicato dos Trabalhadores Rurais de São José de Piranhas/PB e a Pastoral dos Migrantes de Santa Bárbara d'Oeste/SP. Estas duas organizações desenvolvem trabalhos de acompanhamento sindical, pastoral e religioso e tem articulação com estudantes e professores universitários, bem como com outros órgãos como o Ministério Público do Trabalho. Através do Sindicato dos Trabalhadores Rurais de São José de Piranhas/PB tivemos acesso aos trabalhadores nas suas localidades de origem durante o período da entressafra. O Sindicato faz um trabalho de acompanhamento desde o momento da contratação, em geral, em março ou abril de cada ano, até o momento em que os trabalhadores retornam ao município, em geral em novembro ou dezembro. Procuramos acompanhar algumas ações que o sindicato realiza como as reuniões com os trabalhadores e com os "agenciadores" (responsáveis pela organização das turmas), bem como dialogar com os membros da sua diretoria. Isso nos permitiu o contato com os trabalhadores e agenciadores.

Através dos agentes da Pastoral do Migrante de Santa Bárbara d'Oeste/SP, tivemos acesso aos alojamentos onde vivem os trabalhadores migrantes no período da safra. A Pastoral dos Migrantes $^{3}$ é uma organização vinculada a CNBB e que

\footnotetext{
${ }^{3}$ Pastoral do Migrante é uma entidade de católicos brasileiros. De acordo com seu site oficial "A Pastoral do Migrante é um serviço eclesial voltado para a acolhida, orientação e inserção socio-religiosa dos migrantes sob a animação das Congregações dos Missionários e Missionárias Escalabrinianos, que atuam no Brasil em estreito vínculo com o Setor de Mobilidade Humana da Comissão Episcopal para o Serviço da Caridade, da Justiça e da Paz, da CNBB (Conferência Nacional dos Bispos do Brasil) e com o Serviço Pastoral dos Migrantes".Disponível na internet em:
} 
desenvolve um trabalho de assistência religiosa e social aos migrantes, com a promoção de rituais religiosos como as missas, catequese, informações sobre os direitos trabalhistas, realização de palestras e outras atividades.

De maneira geral as usinas não permitem acesso de estranhos para morarem nos alojamentos. Há autores que atribuem os sistemas de alojamento como instituições disciplinárias (Moodie, 1991; Moroney, 1978; Sitas, 1985; Menezes, 2002). São espaços vigiados, com normas próprias e com um rígido controle para entrada e saída de pessoas estranhas. Com as emergentes fiscalizações dos órgãos públicos, (MPF Ministério Público Federal, MTE - Ministério do Trabalho e Emprego, MPT Ministério Público do Trabalho) para combater as práticas ilícitas de condições degradantes do trabalho nos canaviais, a presença de estranhos não é bem vinda, por parte da usina. Comunicar as condições de vida que existem nos alojamentos, pode custar caro, caso for detectado condições degradantes, a usina ou o fornecedor podem ser autuados como infratores por condições de trabalho análogo a escravidão. Isso implica, para a usina, em pagar onerosas multas e ter o nome da empresa divulgado na temida "Lista Suja do Trabalho Escravo". Entre as conseqüências negativas de uma empresa ter nome incluído nesta lista é a de não ficar apta a receber financiamentos público-estatais, e também ter a imagem prejudicada pelo estigma de "empresa escravagista", que dificulta as exportações açúcar e álcool para os países da Europa e América do Norte.

A maioria dos alojamentos é rodeada por cerca ou muros, sendo comum ter uma placa com letras grandes emitindo a mensagem: "PROIBIDA A ENTRADA DE ESTRANHOS". A justificativa de proteger os trabalhadores dos "estranhos" pode ser lida também, como uma iniciativa para isolá-los do contato com algo ou alguém que venha a visibilizar ou comunicar as suas condições de vida.

Nos primeiros contatos com os trabalhadores na Paraíba, ficava claro que não seria agradável a presença de estranhos no alojamento. A justificativa que os próprios trabalhadores e chefes de turma usavam era de que a usina não permitia, mas que se o escritório da usina liberasse não haveria problemas deles me acolherem e hospedarem; afinal os trabalhadores já conheciam o grupo de pesquisa da universidade e os agentes do Sindicato dos Trabalhadores Rurais de São José de Piranhas, que sempre apoiaram a pesquisa.

http://www.pastoraldomigrante.org.br/index.php?option=com content\&view=article\&id=19\&Itemid=49 acesso no dia 22/01/2011. 
Nossa estratégia de inserção aos alojamentos passava pelo trabalho da Pastoral dos Migrantes. A preferência seria pelo Alojamento Horizonte, onde estavam os trabalhadores que já tínhamos acompanhado sua saída em São José de Piranhas.

Para nosso pesquisador (Maciel) poder morar com os trabalhadores migrantes, foi necessário a autorização de um dos proprietários da Usina. Essa autorização foi concedida graças a um pedido de um dos agentes de pastoral que é parente dos proprietários da usina.

Nossa entrada ao alojamento foi possível graças a relações pessoais de confiança. A primeira entre os agentes da Pastoral do Migrante conosco pesquisadores; a segunda relação de confiança foi entre o gerente da área agrícola da usina com o agente de pastoral, que confiava em nós. Esta rede de relações de amizade e parentesco nos permitiu a entrada neste campo.

A interação com os trabalhadores foi se dando aos poucos. O fato de ter guardado na máquina fotográfica digital, algumas imagens do momento em que os trabalhadores se despediram das famílias na saída do ônibus de São José de Piranhas em abril de 2010, foi um elemento que possibilitou a aproximação com alguns trabalhadores. As conversas sobre futebol e os planos para sair em alguma festa e conhecer meninas (por mais que nunca tenham sido realizados) também ajudou na interação.

O fato de ter chegado ao alojamento com um agente da pastoral, porém que era parente dos donos da usina causava certa desconfiança nos trabalhadores. A leitura dos trabalhadores sobre o pesquisador estranho em seu meio foi permanente, mas não impediu a acolhida que também foi se dando gradualmente; através de compartilhar suco e alimentos; jogando futebol; participando de rodas de piadas. Na medida que passavam os dias e diminuíam as desconfianças aumentava as possibilidades de diálogos.

Desde que contrata trabalhadores migrantes, a Usina Peperoni fornece moradia em alojamentos. Em 2010 e 2011 havia cinco alojamentos, três se localizavam nas proximidades da planta industrial da usina, em Santa Bárbara d'Oeste e dois nos canaviais das fazendas, no município de Piracicaba. Nossa inserção de campo aconteceu no Alojamento Horizonte, localizado na zona rural de Piracicaba. Ali residiam 40 trabalhadores, organizados numa turma denominada de "Turma Paraíba 17”. Na Usina Peperoni as turmas são denominadas de acordo com o estado de origem dos trabalhadores migrantes acompanhado por um número. 


\section{A contratação de trabalhadores migrantes na Usina Peperoni}

A paisagem das zonas rurais do estado de São Paulo, sobretudo na região onde fizemos esta pesquisa é caracterizada pela uniformidade das lavouras de cana-de-açúcar. Adentrando nestes canaviais é possível perceber caminhões se movimentando, ônibus levando trabalhadores, trabalhadores cortando cana, máquinas carregando em caminhões que conduz as cargas de cana para a usina, que transforma em álcool e açúcar.

A colheita da cana-de-açúcar é realizada no período de abril a dezembro. No ano de 2010, a Usina Peperoni contratou 300 trabalhadores migrantes para realizar a colheita, ou como é comumente chamado o "corte da cana". "Corte da cana" é uma categoria nativa, utilizada pelos trabalhadores migrantes e por suas famílias do nordeste ao se referirem à atividade canavieira. É comum, ao se conversar com famílias de cortadores de cana que residem no Sertão Paraibano ouvir a expressão: "neste ano pretendo ir pro corte de cana", ou "meu marido foi pro corte de cana".

Nossa pesquisa foi realizada na Usina do Grupo Peperoni, localizada em Santa Bárbara d'Oeste/SP. (Ver mapa anexo). Além da usina, este grupo empresarial possui uma vasta quantidade de terras nos municípios circunvizinhos, onde é plantada a matéria prima para a fabricação do açúcar e do etanol. Os trabalhadores que atuam na área agrícola, sobretudo na chamada "frente de corte" (que é responsável pelo corte da cana-de-açúcar), são migrantes temporários, originários da Região Nordeste do Brasil, mais precisamente das micro-regiões de Cajazeiras/PB e micro-região sul cearense (municípios de Barro e Mauriti/CE).

Sr. Galvão trabalhou na Usina Peperoni desde a década de 1980 até em 2005, quando foi aposentado devido a um acidente de trabalho. De acordo com o seu relato em visita a campo no mês de maio de 2010, a contratação de trabalhadores migrantes paraibanos e cearenses começou na década de 1980 e foi fortalecida na década de 1990. Ele diz que, quando começou a trabalhar nesta usina, não havia trabalhadores provenientes de outros estados, a cana era colhida por trabalhadores que moravam no regime de colonato nas terras da usina. Os colonos se mudaram para a cidade, os seus filhos passaram a trabalhar nas indústrias da região, e a usina passou a contratar trabalhadores que moravam nas periferias das cidades da região. Em seguida é que entram os trabalhadores migrantes, sobretudo provenientes de Minas Gerais e posteriormente do estado da Bahia. Porém, com as greves realizadas na década de 1990, 
os mineiros e baianos foram substituídos pelos cearenses e paraibanos, que segundo Sr. Galvão são pessoas "mais fáceis de lidar", no sentido de que não provocam greves.

Nossa etnografia foi realizada com trabalhadores da safra 2010, identificados pela usina como “Turma Paraíba 17”, que é formada por moradores do distrito rural de Boa Vista, município de São José de Piranhas/PB através de um arregimentador chamado Sr. Felipão, o qual era cortador de cana e ascendeu na hierarquia passando a ser arregimentador de trabalhadores. Ele migra para o "corte de cana", desde a década de 1990.

Até 1989 o chamado "corte de cana" não era conhecido pelos habitantes dessa pequena vila paraibana. Até que um morador, Sr. Pretinho, migrou para o estado de São Paulo para "tirar uma safra", expressão utilizada para denominar o processo de migração para a colheita da cana-de-açúcar. Quando voltou em dezembro, Pretinho convidou mais três amigos, dentre eles seu Felipão, para no ano seguinte irem aos canaviais. Em 1991, Sr. Felipão e Sr. Pretinho organizaram uma turma de 60 homens para trabalhar nesta usina. Sr. Pretinho, por ser mais velho, deixou de fazer este processo de migração. Sr. Felipão continuou. Assim se constituiu a atual turma "Paraíba 17", que atualmente conta com 40 trabalhadores pelas significativas reduções de postos de trabalho ocasionadas pela entrada de máquinas na colheita da cana. Na década de 1990 a turma tinha 60 trabalhadores, no começo dos anos 2000 a turma contava apenas com 45 trabalhadores e nas últimas três safras o número se manteve constante em 40 membros.

Sr. Felipão, organiza a turma a partir de sua rede de contatos, de suas pessoas conhecidas e dos pedidos que chegam até ele para "arranjar" uma vaga na turma. Para fazer parte da turma "Paraíba 17" é necessário, além de atender as exigências colocadas pela usina, uma afinidade com Sr. Felipão ou com algum conhecido dele. Na localidade de origem dos trabalhadores migrantes, a pessoa que organiza a turma é denominada de "turmeiro". Na estrutura hierárquica da usina, esse mesmo agente é denominado de "fiscal", e irá cumprir com uma lista de tarefas determinadas pela usina.

\section{Os alojamentos como espaços de controle da força de trabalho}

Desde 1991, quando Sr. Felipão faz este trabalho organizativo, suas turmas são acomodadas no Alojamento Horizonte, formado por 6 casas de quatro cômodos cada Localizado na sede da antiga Fazenda Horizonte. Este espaço, hoje denominado de 
Alojamento Horizonte, tem instalações para abrigar 140 pessoas, porém a turma de 2010 tem apenas 40 homens. "Alojamento" é a denominação posta pela usina, os trabalhadores chamam este espaço de "barracos".

As casas que hoje abrigam os trabalhadores migrantes foram construídas inicialmente para serem utilizados por famílias dos chamados colonos, descendentes de italianos que migraram para o Brasil no começo do século $\mathrm{XX}$, que trabalhavam nas plantações de café. A lavoura de café foi substituída por cana-de-açúcar, a Fazenda Horizonte foi adquirida pelos atuais proprietários da usina e os colonos foram substituídos por trabalhadores migrantes temporários vindos da Região Nordeste.

A literatura acadêmica tem tratado estes espaços de moradia dos trabalhadores migrantes como espaços de controle (Menezes 2002, Sitas 1985), que visa disciplinar o corpo e o tempo dos trabalhadores para melhor servir aos interesses de produtividade da usina. No Alojamento Horizonte identificamos uma rotina organizada a partir de uma programação proposta pela usina. Os trabalhadores começam a se levantar por volta das 5h. Uns lavam roupas; outros se dirigem ao refeitório para tomar café; outros preferem dormir até as $6 \mathrm{~h}$. O ônibus que leva os trabalhadores aos canaviais sai do alojamento as $6 \mathrm{~h} 20 \mathrm{~m}$. Até essa hora todos os trabalhadores devem estar acordados e vestidos adequadamente com seu material de trabalho.

Por volta das $17 \mathrm{~h}$ o ônibus da usina trás os trabalhadores de volta ao alojamento. Assim que chegam os trabalhadores se organizam para tomar banho; lavar roupas; fazer ligações telefônicas para suas famílias. A janta é servida até às $19 \mathrm{~h}$. As $21 \mathrm{~h}$ todos são convidados a se recolherem e dormir.

Algumas proibições expressas pela usina demonstram uma tentativa de controlar o tempo livre dos trabalhadores. É proibido o pernoite de esposas, namoradas ou prostitutas, e até mesmo parentes que venham visitar. A tônica das respostas dos encarregados da usina para fundamentar essa regra circula em torno da ideia de que o alojamento é um espaço de descanso. Faz-se o máximo para evitar eventos que atrapalhem o descanso dos trabalhadores. Isso pode nos revelar uma intenção da usina de controlar o tempo livre, para que estando mais descansado, o trabalhador tenha melhor produtividade no trabalho. A mesma argumentação serve para a proibição da utilização de televisores nos quartos. No alojamento existe uma sala com uma televisão, que fica ligada até as $21 \mathrm{~h}$, com exceção nas quartas-feiras a noite que há jogos de futebol e a TV fica ligada até as 23h, se algum trabalhador desejar assistir. Após o fiscal desliga e todos são convidados a dormir. 
Estas duas regras que buscam regulamentar o tempo livre dos trabalhadores, com a finalidade de zelar pelo seu descanso e consequentemente aumento de produtividade, só é possível se os trabalhadores moram na propriedade da usina.

O segundo elemento que leva a crer que a usina busca controlar o tempo livre dos trabalhadores é o fato do fiscal morar no alojamento e executar as regras prescritas pelo corpo diretor da usina. $\mathrm{O}$ fiscal tem que garantir a vigilância do alojamento; proibir a hospedagem de mulheres ou parentes; garantir o silêncio durante o período de descanso; punir trabalhadores que saem para festas e chegam muito tarde ao alojamento. O terceiro elemento que evidencia tal iniciativa é o fato de que, localizada no lado de cada alojamento de trabalhadores desta usina, se encontram casas de encarregados, como podemos observar no croqui Alojamento Horizonte.

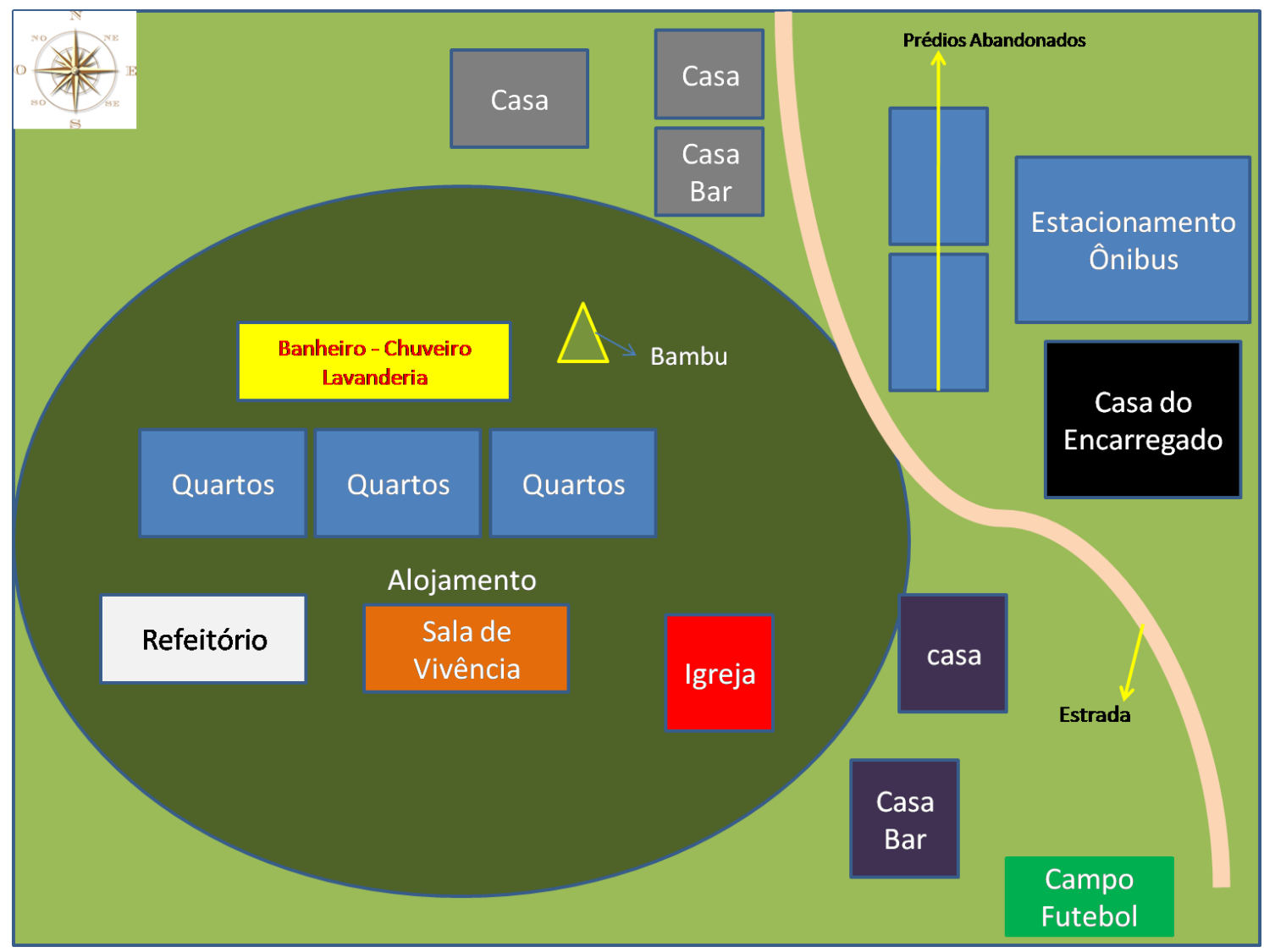

Imagem 1: Croqui Alojamento Horizonte. 
No círculo com a cor mais escura localiza-se o espaço do alojamento. Neste espaço encontram-se as instalações dos banheiros, lavanderia, quartos, refeitório, sala de vivência, templo da Igreja e um pé de bambu, onde os trabalhadores costumam esconder bebidas alcoólicas. Na parte direito, após esta linha torta que representa a estrada, está localizada a casa do encarregado de fazenda, que é responsável por coordenar todos as turmas e os turmeiros. É uma espécie de capataz. Na hierarquia de poder ele se encontra logo abaixo dos proprietários. Nas outras casas que se encontram na periferia do circulo moram o motorista e um encarregado aposentado.

Como já apresentamos em outros trabalhados (Cover, 2011) há uma hierarquia de poder que se estabelece no interior dos canaviais. Os cortadores são coordenados pelos fiscais. Cada turma de 40 trabalhadores está sob o comando de um fiscal. Os fiscais sob o comando de dois encarregados gerais. Os encarregados gerais se reportam ao diretor do setor agrícola, que nesta usina é um dos acionistas majoritários do grupo. O desenho a seguir busca demonstrar essa hierarquia.

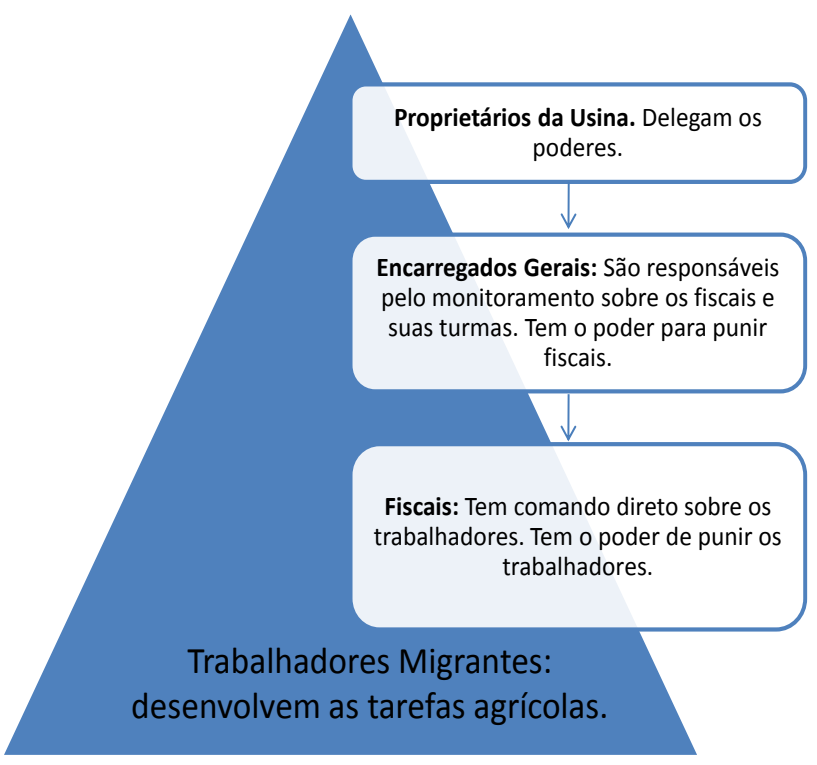

Imagem 2: Pirâmide de Hierarquia de Poder. 
A seguir organizamos uma tabela para detalhar melhor as funções de cada agente nesta hierarquia:

\begin{tabular}{|l|l|}
\hline Posição & Função \\
\hline Proprietários da Usina & $\begin{array}{l}\text { São quem detêm o controle legal dos meios de } \\
\text { produção e do processo de produção }\end{array}$ \\
\hline Encarregados & $\begin{array}{l}\text { São o elo entre os proprietários e os trabalhadores. } \\
\text { Supervisionam todas as atividades relacionadas ao } \\
\text { corte de cana. Na Usina Peperoni são dois } \\
\text { funcionários que fazem esta função. São } \\
\text { subordinados apenas aos proprietários. }\end{array}$ \\
\hline Fiscais & $\begin{array}{l}\text { São subordinados diretos dos encarregados. Tem a } \\
\text { função de organizar a turma de cortadores para que } \\
\text { o trabalho seja executado de acordo com as } \\
\text { normas técnicas da usina. Tem poder para punir os } \\
\text { trabalhadores. Tem responsabilidade para manter a } \\
\text { disciplina nos alojamentos. }\end{array}$ \\
\hline Medidores & $\begin{array}{l}\text { Seu trabalho é medir a quantidade de cana cortada } \\
\text { por dia por cada trabalhador. Não tem poder para } \\
\text { punir trabalhador. }\end{array}$ \\
\hline
\end{tabular}

Tabela 1: Funções hierárquicas dos agentes.

A tabela a seguir, sintetiza o processo de constituição da atual estrutura hierárquica das usinas. 
ALOJAMENTOS DE TRABALHADORES MIGRANTES..

\begin{tabular}{|c|c|c|c|c|c|}
\hline Década de 1970 & Usineiros & \multicolumn{2}{|c|}{ Mediador } & \multicolumn{2}{|c|}{ Trabalhador } \\
\hline \multirow[t]{2}{*}{ Necessita } & $\begin{array}{l}\text { Trabalhadores } \\
\text { que cortem } \\
\text { cana-de-açúcar }\end{array}$ & \multicolumn{2}{|c|}{ Sustentar a si e a família } & \multicolumn{2}{|c|}{ Sustentar a si e a família } \\
\hline & $\begin{array}{l}\text { Alguém que } \\
\text { traga os } \\
\text { trabalhadores } \\
\text { até a usina }\end{array}$ & \multicolumn{2}{|c|}{ Alguém que lhe ofereça trabalho } & \multicolumn{2}{|c|}{$\begin{array}{l}\text { Alguém que lhe ofereça } \\
\text { trabalho }\end{array}$} \\
\hline Oferece & $\begin{array}{l}\text { Postos de } \\
\text { trabalho }\end{array}$ & \multicolumn{2}{|c|}{$\begin{array}{l}\text { Trabalhadores a quem necessita } \\
\text { de trabalhadores e trabalho a } \\
\text { quem necessita de trabalho. }\end{array}$} & \multicolumn{2}{|c|}{ Força de trabalho } \\
\hline $\begin{array}{lr}\text { Que } & \text { serviço } \\
\text { presta } & \text { nessa } \\
\text { cadeia } & \end{array}$ & $\begin{array}{l}\text { Oferece postos } \\
\text { de trabalho. }\end{array}$ & \multicolumn{2}{|c|}{$\begin{array}{l}\text { 1)Transporta os trabalhadores. } \\
\text { 2)Fiscaliza o trabalho. }\end{array}$} & \multicolumn{2}{|c|}{ Desenvolve tarefas agrícolas. } \\
\hline $\begin{array}{l}\text { Como } \\
\text { renumerado? }\end{array}$ & $\begin{array}{l}\text { Através } \\
\text { realização da } \\
\text { capital investido } \\
\text { no processo de } \\
\text { produção do } \\
\text { açúcar e etanol }\end{array}$ & \multicolumn{2}{|c|}{$\begin{array}{l}\text { Ganha uma } \\
\text { produtividade } \\
\text { trabalhador }\end{array}$} & \multicolumn{2}{|c|}{ Salário por produção. } \\
\hline $\begin{array}{l}\text { Mudanças nos } \\
\text { anos } 1980\end{array}$ & \multicolumn{5}{|c|}{$\begin{array}{l}\text { A atividade industrial urbana em São Paulo atrai a força de trabalho rural. As usinas } \\
\text { passam a contratar trabalhadores migrantes de áreas rurais de Minas Gerais e da } \\
\text { Bahia. }\end{array}$} \\
\hline \multirow{3}{*}{$\begin{array}{l}\text { Novos agentes } \\
\text { na cadeia }\end{array}$} & \multicolumn{5}{|c|}{ Entra em cena o trabalhador rural migrante, e também o "turmeiro" nordestino. } \\
\hline & Usineiros & $\begin{array}{l}\text { Mediador } \\
\text { Paulista }\end{array}$ & $\begin{array}{l}\text { Mediador } \\
\text { Nordestino }\end{array}$ & $\begin{array}{l}\text { Trabalhador } \\
\text { Paulista }\end{array}$ & $\begin{array}{l}\text { Trabalhador } \\
\text { Nordestino }\end{array}$ \\
\hline & $\begin{array}{l}\text { Oferece postos } \\
\text { de trabalho }\end{array}$ & $\begin{array}{l}\text { Traz os } \\
\text { trabalhadores } \\
\text { para os } \\
\text { canaviais }\end{array}$ & $\begin{array}{l}\text { Organiza } \\
\text { turmas de } \\
\text { trabalhadores } \\
\text { nas localidades } \\
\text { de origem. }\end{array}$ & $\begin{array}{lr}\text { Oferece } & \text { sua } \\
\text { força } & \text { de } \\
\text { trabalho } & \end{array}$ & $\begin{array}{lr}\text { Oferece } & \text { sua } \\
\text { força } & \text { de } \\
\text { trabalho } & \end{array}$ \\
\hline \multirow[t]{3}{*}{$\begin{array}{l}\text { Mudanças nos } \\
\text { anos } 1990\end{array}$} & \multicolumn{5}{|c|}{$\begin{array}{l}\text { As greves realizadas pelos trabalhadores migrantes originários da Bahia e Minas } \\
\text { Gerais, estimulam os mediadores a preferirem a contratação de trabalhadores } \\
\text { migrantes dos estados da Paraíba e do Ceará, por consideram os paraibanos e } \\
\text { cearenses como mais "fáceis" de lidar. Paulatinamente, a usina ficou somente com } \\
\text { trabalhadores migrantes em seus canaviais. }\end{array}$} \\
\hline & Usineiros & $\begin{array}{l}\text { Mediador } \\
\text { Paulista }\end{array}$ & $\begin{array}{l}\text { Mediador } \\
\text { Nordestino }\end{array}$ & $\begin{array}{l}\text { Trabalhador } \\
\text { Paulista } \\
\end{array}$ & $\begin{array}{l}\text { Trabalhador } \\
\text { Nordestino }\end{array}$ \\
\hline & $\begin{array}{l}\text { Oferece postos } \\
\text { de trabalho }\end{array}$ & $\begin{array}{l}\text { Passa a atuar } \\
\text { com a } \\
\text { contratação de } \\
\text { trabalhadores } \\
\text { migrantes }\end{array}$ & $\begin{array}{l}\text { Organiza } \\
\text { turmas de } \\
\text { trabalhadores } \\
\text { nas localidades } \\
\text { de origem. }\end{array}$ & $\begin{array}{l}\text { É cada vez } \\
\text { menos } \\
\text { presente nos } \\
\text { canaviais. } \\
\text { Busca se } \\
\text { empregar em } \\
\text { outras } \\
\text { atividades. }\end{array}$ & $\begin{array}{l}\text { Passa a ser a } \\
\text { maioria nos } \\
\text { canaviais. }\end{array}$ \\
\hline $\begin{array}{l}\text { Mudanças nos } \\
\text { anos } 2000\end{array}$ & \multicolumn{5}{|c|}{$\begin{array}{l}\text { É criada uma lei que pró́be a terceirização de trabalhadores nos canaviais. Isso } \\
\text { reconfigura a função dos agentes. }\end{array}$} \\
\hline & Usineiros & $\begin{array}{l}\text { Mediador } \\
\text { Paulista }\end{array}$ & $\begin{array}{l}\text { Mediador } \\
\text { Nordestino }\end{array}$ & \begin{tabular}{l|} 
Trabalhador \\
Paulista
\end{tabular} & $\begin{array}{l}\text { Trabalhador } \\
\text { Nordestino }\end{array}$ \\
\hline & $\begin{array}{lr}\text { Não pode } & \text { mais } \\
\text { terceirizar } & \text { as } \\
\text { funções } & \text { nos } \\
\text { canaviais. } & \text { A } \\
\text { terceirização é } \\
\text { proibida por lei. }\end{array}$ & $\begin{array}{l}\text { É incorporado } \\
\text { como } \\
\text { encarregado }\end{array}$ & $\begin{array}{l}\text { É contratado } \\
\text { pela } \quad \text { usina } \\
\text { como fiscal }\end{array}$ & $\begin{array}{l}\text { É contratado } \\
\text { diretamente } \\
\text { na usina, } \\
\text { porém em } \\
\text { número } \\
\text { reduzido. }\end{array}$ & $\begin{array}{l}\text { É contratado } \\
\text { diretamente } \\
\text { na usina, em } \\
\text { maior } \\
\text { número. }\end{array}$ \\
\hline
\end{tabular}

Tabela 2: Constituição da estrutura hierárquica das usinas. 
De maneira geral podemos perceber que existem três figuras distintas que perpassam os diferentes períodos históricos que demarcamos. Existem os usineiros (que detém os meios de produção); os trabalhadores (que oferecem a força de trabalho) e uma terceira figura, uma espécie de intermediário, que organiza a força de trabalho, através de métodos bastante particulares.

O fato é que a partir da década de 1980 passam a entrar neste cenário os trabalhadores migrantes temporários. Com esta modificação no perfil dos trabalhadores, cria-se também a figura do "turmeiro" migrante (o fiscal), ou seja, um arregimentador que geralmente é um cortador de cana mais velho, que já migra há mais tempo pro corte de cana e que desenvolveu a habilidade de coordenar/comandar as turmas.

Nem por isso os usineiros dispensam os trabalhos dos antigos arregimentadores, os chamados gatos (Silva, 1999), que passam a ser encarregados gerais, supervisionando o trabalho dos fiscais, para garantir a produtividade dos trabalhadores.

Através desta distribuição de tarefas e de poder, os contratadores da força de trabalho têm organizado um processo eficiente de extração de horas de trabalho dos contratados.

Esta estrutura organizativa é constitutiva do mundo do "corte da cana". As diferentes posições sociais materializadas em tarefas no processo de trabalho são reforçadas por elementos de distinção, que revelam a reprodução dessa estrutura de poder.

Assim temos os cortadores e os fiscais que moram nos alojamentos. Os encarregados moram em casas com suas famílias (esposa e filhos). Além dos diferentes espaços de moradia, há outros elementos de distinção que podem ser considerados como diferenciadores dos atores sociais.

No ônibus que leva os trabalhadores até o canavial, os acentos são marcados. O fiscal e o medidor ficam sentados nos dois primeiros bancos, próximos ao motorista. Os encarregados vão para o canavial de carro. Nas folgas os lugares freqüentados por cortadores, fiscais e encarregados também são diferenciados e diferenciadores. De maneira geral todos frequientam o bar mais próximo ao alojamento, mas o Clube dos Metalúrgicos (um salão de festas onde só é permitida a entrada com roupa social) é apenas freqüentado por fiscais ou pelo encarregado.

Então, a partir do momento em que as usinas passam a contratar trabalhadores migrantes, os espaços de moradia destinados a trabalhadores nas fazendas passam a se tornar alojamentos. Além de um local físico o alojamento também é um local social, ou 
seja, um espaço destinado para o descanso e controle dos trabalhadores. Um local social que os trabalhadores não chamam de casa, mas sim de "barraco", ou seja, um local social transitório.

\section{Os códigos de conduta e a sabedoria para viver em "barracos"}

Para tratar dos códigos de conduta, um tema caro para entender a sociabilidade dos trabalhadores migrantes no interior do setor do Agronegócio Canavieiro, ou no mundo do "corte de cana" vamos expor duas situações, que fornecem expressões chaves para explicar este mundo: Por que o cara já sabe o tranco e saber viver nos barracos.

Na entrevista realizada no alojamento em outubro de 2010, com Neimar, um cortador de cana, 23 anos, ele disparou a seguinte frase: "Por que o cara já sabe o tranco". Ao ouvirmos a frase, ficamos surpresos, até por que a afirmação foi dita sem um prévio estímulo da pergunta. Segue abaixo o trecho da entrevista em que aparece a frase:

P: E além dessa dificuldade que tu falou da TV, que outros problemas tu vê? (Da vida em alojamento).

Neimar: Eu acho que deveria ter mais higiene aqui nos barracos, que não tá tendo. Só um zelador pra zelá de um monte de barraco como desse aqui! E os banheiros lá você vê! É zelado uma vez por dia! E devia ser zelado duas vezes por dia.

$P: A h, t a \ldots$

Neimar: Acho que as maiores é essas aí.

P: Aham...

Neimar: Em termo de roça eu nem esquento, por que o cara já sabe o tranco!(Entrevista com o cortador de cana Neimar, Piracicaba, outubro de 2010).

A pergunta era relacionada às dificuldades da vida em alojamento, mas a resposta revelou o significado atribuído pelo trabalhador ao cotidiano do trabalho. Talvez suspeitasse que se pudesse perguntar sobre as dificuldades que existem no trabalho, e quisesse se antecipar na resposta. Talvez, para este trabalhador, a dissociação analítica que pode ser feita entre espaço de moradia e espaço de trabalho não faça sentido, afinal, tudo faz parte do mundo do "corte de cana". De qualquer forma revelou que em termos de "roça" ele não "esquenta", por que "o cara já sabe o tranco". Ao se referir ao "cara" e não a si próprio, é possível ler como uma descrição que o camponêstrabalhador faz não apenas de si, senão, provavelmente teria usado o pronome em primeira pessoa. Como se referiu a uma terceira pessoa, no caso, "o cara”, estaria ele descrevendo além de si, os demais trabalhadores que fazem este processo de migração para o corte de cana? Estaria ele formulando uma espécie de personagem para explicar 
sobre a sua situação e a situação dos seus iguais? O seguinte trecho da entrevista pode dar mais pistas:

P: Sim! Como assim em termos de roça?

Neimar: Por que os caras só falam que a roça "não, é ruim de trabalhar", mas o cara já sabe que trabalha, a carga horária aqui como é que é.

$P$ : É pesada sim...

Neimar: É! Já sabe! Já sai da Paraíba eles já explica. O alojamento também eles explica, mas só que eles quer exigir da gente, mas não quer oferecer nada também em troca né, das exigências que eles dão.

$P:$ Aham...

Neimar: Se eles exigissem que pelo menos oferecessem alguma vantagem! Olha o armário (risos irônicos) bonito pra caramba. (mais risos irônicos).

(Entrevista com o cortador de cana Neimar, Piracicaba, outubro de 2010)

Na primeira frase de Neimar, neste trecho, podemos perceber que quando falou "os caras", se referiu a seus colegas, que reclamam das condições de trabalho, como se não soubessem que o trabalho seria difícil, penoso. Para Neimar, a reclamação dos companheiros é desnecessária. Por que reclamar se já sabe como é o "tranco"? Ora, o corte de cana não é um lugar para desavisados! Assim, o discurso de Neimar, nos oferece pistas para entender como é esse lugar, quais as regras que se constituem e regem esse espaço social.

Em seguida, na afirmação "se eles exigissem, que pelo menos oferecessem alguma vantagem!"’, Neimar indica uma critica as condições de moradia baseada na expectativa dos trabalhadores sobre as obrigações da usina para com os trabalhadores. De certo modo, poderíamos dizer que essa expectativa é medida por uma regra de reciprocidade, ou seja, os trabalhadores reconhecem a exigência das usinas de produtividade, mas esperam que ela em contrapartida ofereça condições de trabalho e moradia.

Ora! Se "eles" (no caso o trabalhador refere-se à usina) exigem, é necessário que ofereçam algo. Ou seja, a usina deveria, ao menos, oferecer condições melhores de alojamento que atendessem níveis de decência, como bons armários; camas confortáveis; ambiente limpo; mais espaço nos quartos (num quarto com $6 \mathrm{~m}^{2}$ ficam quatro trabalhadores). E então ri da situação dos armários que existem no alojamento, o qual considera que estão em condições precárias. Se, de um lado, os trabalhadores em sua narrativa demonstram que conhecem bem as regras do trabalho, através da expressão "o cara já sabe o tranco da roça", de outro lado, também demonstram sabedoria sobre as regras de sociabilidade no mundo dos canaviais, quando usam a expressão: "Saber viver em barraco" 
$\mathrm{Na}$ segunda visita de nosso pesquisador Maciel, em outubro de 2010, um cortador de cana chamado César, o convidou para tomar cachaça com seus amigos. A ingestão de bebidas que contenham álcool é proibida no alojamento. Mas, os trabalhadores bebem cachaça, rum, uísque e conhaque. Essa prática, porém, é organizada com uma série de práticas de dissimulação, de modo a impedir que o fiscal seja informado que tais trabalhadores estão desrespeitando a regra. Há dois procedimentos básicos: o primeiro trata-se de esconder a bebida; o segundo trata-se de impedir a aproximação de "caguetes", pessoas que venham a entregar tal descumprimento da regra ao fiscal.

Este grupo de trabalhadores esconde a cachaça num dos armários que se localiza num quarto, que naquele momento, não está sendo ocupado como dormitório. Chegando neste local (Maciel/pesquisador) e César (cortador de cana). Tiago e Mateus (dois cortadores amigos de César e participantes do grupo que bebe cachaça) já estão dentro do quarto. César bate na porta e fala "sou eu". Os de dentro reconhecem sua voz e abrem a porta. Ao entrar a porta é novamente fechada. Tiago, que tem a chave, abre o armário, pega o litro da cachaça Velho Barreiro e se serve bebendo meio copo num gole. Ele passa o copo e o litro para Maciel, que também se serve, porém bebendo apenas um golinho, pois não é acostumado com a bebida. César e Mateus se servem, posteriormente, também bebem meio copo, em apenas um gole. Todos sentam no chão, em forma de círculo, para conversar. No meio da roda, além do litro e do copo, há o saco de salgadinhos, que serve como aperitivo, para acompanhar a bebida, e também como artifício para disfarçar numa possível chegada de "caguetes". Constantemente, alguém bate na porta para entrar. Então Tiago guarda o litro de cachaça, e Mateus abre a porta. Se for um amigo deste grupo e não for "caguete", o mesmo é convidado a entrar. Se for caguete é pouca conversa e a porta é fechada. Numa das batidas era um trabalhador chamado de Calango, e este é convidado para entrar. Calango bebeu um copo num gole só. Na outra batida, era Guilherme. Com este o diálogo travado por Mateus foi monossilábico, e a porta elegantemente fechada.

Segundo Tiago, há apenas dois "caguetes" no alojamento. Um destes é o medidor que tem apelido de Coro Veio; o outro é um novato, que se chama Guilherme. Tiago me explica que Coro Veio é medidor, portanto tem o dever de entregar os descumpridores de regras, para o fiscal. E Guilherme é "novato" e "não sabe viver no barraco", e na dúvida é melhor não convidá-lo. 
E nessa conversa, regada de Velho Barreiro, Tiago ao me explicar quem são os caguetes, fornece uma fala, que usaremos como chave para entender o mundo destes cortadores de cana. Por que o que se passa é o seguinte: é de se esperar que o medidor, ao ver os trabalhadores bebendo cachaça no alojamento, informe ao fiscal. É esperado por que faz parte do ofício do medidor, e também do fiscal, vigiar os cortadores de cana. E os trabalhadores naturalizam, aceitam esse fato, por que isso já lhes é explicado antes mesmo de sair da Paraíba. E no caso de Guilherme, também é de se esperar que informe ao fiscal, pelo fato dele ser novato, de ser seu primeiro ano no "corte de cana". E, portanto, nas palavras de Tiago, ele "não sabe viver em barraco". Barraco é como os trabalhadores se referem ao alojamento. Diante disso me veio à questão: o que é saber viver em barraco? Que "sabedoria" é necessária para viver e conviver neste mundo social dos canaviais? Saber viver em barracos implica num processo social de aprendizagem? Aprender a viver em barraco está relacionado a uma experiência pessoal e coletiva?

Os dois elementos são relacionados a uma sabedoria. No primeiro episódio, Neimar afirma, "por que o cara já sabe o tranco". No segundo episódio, Tiago informa “o novato não sabe viver em barraco". Estas "sabedorias" demarcam as práticas de sociabilidade dos camponeses-trabalhadores migrantes nos canaviais. Estas sabedorias nos fornecem chaves para compreender alguns códigos de sociabilidade neste espaço social marcado por vigilância, repressão, dominação, mas, também, práticas de resistência (Scott, 1985, 1990, 2003) ou por táticas (Certeau, 1994).

A máxima de Foucault “onde há poder há resistência" pode ser utilizada para descrever as atitudes dos trabalhadores nos alojamentos. Os trabalhadores não aceitam passivamente o processo de submissão.

As regras no alojamento são criadas pelo corpo gerencial da usina, ditas de boca em boca e aos que não as cumprem os pedagógicos ganchos estimulam determinado tipo de conduta neste espaço social.

Mas para a regra de que não se pode beber cachaça no alojamento, os trabalhadores arranjam um jeito de colocar a cachaça em locais seguros e bebem quando o fiscal não está.

Se a usina proíbe que se tenha televisão nos quartos, os trabalhadores não um jeito de ter sua TV para assistir os filmes que bem entenderem ouvir as músicas que lhe fazem recordar das festas e dos bons tempos de descanso no nordeste. 
É possível considerar essas práticas de insubordinação como resistência? Certamente é uma resposta complexa, devido à complexidade de como se monta a cena social onde acontecem essas tramas de dominação e resistência.

As atitudes que os trabalhadores têm, diante de um quadro onde um agente com força maior busca controlar o tempo livre, nos desautoriza a falar que os trabalhadores são passivos ou alienados. Na mesma medida também essa realidade não nos autoriza a falar que estas práticas de insubordinação, que guardada as devidas proporções podem ser comparadas ao que Silva (2008) tem chamado de "resistência miúda" ou nos termos de Scott (1985) "resistência cotidiana", mostram alteração na correlação de forças entre os trabalhadores e seus contratadores.

Estes micro-atos, neste contexto caracterizam as contradições estruturais na sociabilidade no "mundo do corte de cana".

O consenso que se apresenta no discurso público que aceita que "o tranco da roça", a exploração e as condições de trabalho "são assim mesmo", é constantemente negado nos bastidores, nos espaços do trabalho e moradia.

Porém, no "saber viver no barraco", percebe-se que esse processo de disciplinamento, de dominação, de exploração é constantemente negado. Os micro-atos de dissimulação, como: beber cachaça ou assistir televisão; num primeiro momento não pareçam provocar transformações nas relações, mas informam que ali não se encontra uma massa atomizada, "dócil”, para ser explorada. Estas práticas informam que ali se encontram sujeitos humanos, que compartilhar a idéia de que por mais que "o barraco" e o "corte da cana" seja uma fase transitória de suas trajetórias, se desrespeitados de sua "razão", de sua noção de justiça, eles reagem. Claro, reagem de acordo com sua sabedoria, com sua racionalidade.

\section{Considerações Finais}

Os "fracos", para usar o termo de Scott, também tem suas "armas", e as utilizam conforme se apresenta a ocasião. E por mais romântica que pareça a constatação de que é uma falácia afirmar que os trabalhadores migrantes são "dóceis", é trágica a constatação de que a ausência de uma ação organizada de dês-naturalização, de contestação da exploração do agronegócio canavieiro, é um limite para a melhoria das condições de moradia e trabalho, tanto nos transitórios "barraco e corte da cana", como nas localidades de origem no sertão paraibano. 
O "corte da cana" é representado como uma passagem demarcada no tempo e no espaço. Num tempo renovado ou não em cada safra, e com um prazo certo pra acabar, pois cada cortador por questões de saúde e competitividade migrará no máximo até os 40 anos de idade. E também pelos espaços físicos transitórios, materializados na expressão "barracos", ou seja, um espaço que não é pra sempre, é uma passagem necessária na trajetória do trabalhador migrante.

A transitoriedade do "corte de cana", tanto no espaço social do trabalho como no espaço social de moradia, é um elemento fundamental para analisar a sociabilidade destes trabalhadores e seus comportamentos individuais e coletivos diante do seu processo de exploração do trabalho.

\section{Referências}

ALVES, Francisco. "Migração de trabalhadores rurais do Maranhão e Piauí para o corte de cana em São Paulo: será esse um fenômeno casual ou recorrente da estratégia empresarial do Complexo Agroindustrial Canavieiro?". In: NOVAES, Roberto e ALVES, Francisco (Org's). Migrantes: trabalho e trabalhadores no Complexo Agroindustrial Canavieiro (Os heróis do Agronegócio Brasileiro). São Paulo: Ed. UFSCar, 2007.

AUGRAS, Monique. "História Oral e Subjetividade". In: VON SIMSOM, Olga. R. M. (Org.). Os Desafios Contemporâneos da História Oral. São Paulo: Ed. Unicamp,1997.

CÂNDIDO, Paulo. Paradeiros e Revoltas dos Canavieiros Alagoanos entre 2007/2009. Campina Grande: UFCG, 2011. (Tese de Doutorado)

CERTEAU, Michel de. A Invenção do cotidiano. Artes de fazer. Petrópolis: Vozes, 1994.

COVER, Maciel. O "tranco da roça" e a "vida no barraco": um estudo sobre trabalhadores migrantes no setor do agronegócio canavieiro. João Pessoa: Ed. Universitária UFPB, 2011.

FOUCAULT, Michel. Microfísica do poder. Rio de Janeiro: Ed. Graal, 1979.

GUANAIS, Juliana B. No eito da cana, a quadra é fechada: estratégias de dominação e resistência entre patrões e cortadores de cana em Cosmópolis/SP. São Paulo: UNICAMP, 2010. (Dissertação de Mestrado).

MENEZES, Marilda Aparecida de. Redes e enredos nas trilhas dos migrantes: um estudo de famílias de camponeses-migrantes. Rio de Janeiro: Relume Dará/ João Pessoa: UFPB, 2002.

MENEZES, Marilda, (et.al). "Construindo narrativas orais : interações sociais no trabalho de campo". In: Cadernos de Campo, v.13. n.12. São Paulo: PPGAS/ USP, 2004.

MOODIE, D. "Social existence and the pratice of personal integrity. Narratives of resistance on the South African Gold Mines". In: African Studies, v.50, n1-2. Johannesburg: University of the Witwatersrand; Routledge, 1991. p. 39-63. 
MORONEY, S. "The development of the compound as a mechanism of worker control 1900-1912". In: South African Labour Bulletin, v. 4, n.3. Durban: Umanyano Publications, 1978. p.29-49.

NOVAES, José Roberto Pereira. "Trabalho nos canaviais: os jovens entre a enxada e o facão". In: RURIS, v. 3, n.1. Campinas: CERES-IFCH/ Unicamp; NEAD, 2009.

SCOTT, James. Weapons of the weak: the everyday pratices of resistance. New Haven: Yale University Press, 1985.

SILVA, Marcelo Saturnino. Trabalhadores Migrantes nos canaviais paulistas: sociabilidades, Trabalho e formas de resistência. Campina Grande: UFCG, 2011. (Tese de Doutorado).

SILVA, Maria Aparecida de M. "Cortadores de cana e os (não) direitos". In: Travessia, maio-agosto. São Paulo: CEM, 2008. p. 26-36.

SILVA, Maria Aparecida de Moraes. Errantes do Fim do Século. São Paulo: Ed. da Unesp, 1999.

SITAS, A. Moral Formation and struggles amongst migrant worers on the East Rand. In: Labour, Capital and Society, v. 18 n.2, nov. 1985. Halifax: Saint Mary's University, 1985. p. 372-401.

Anexo 1:

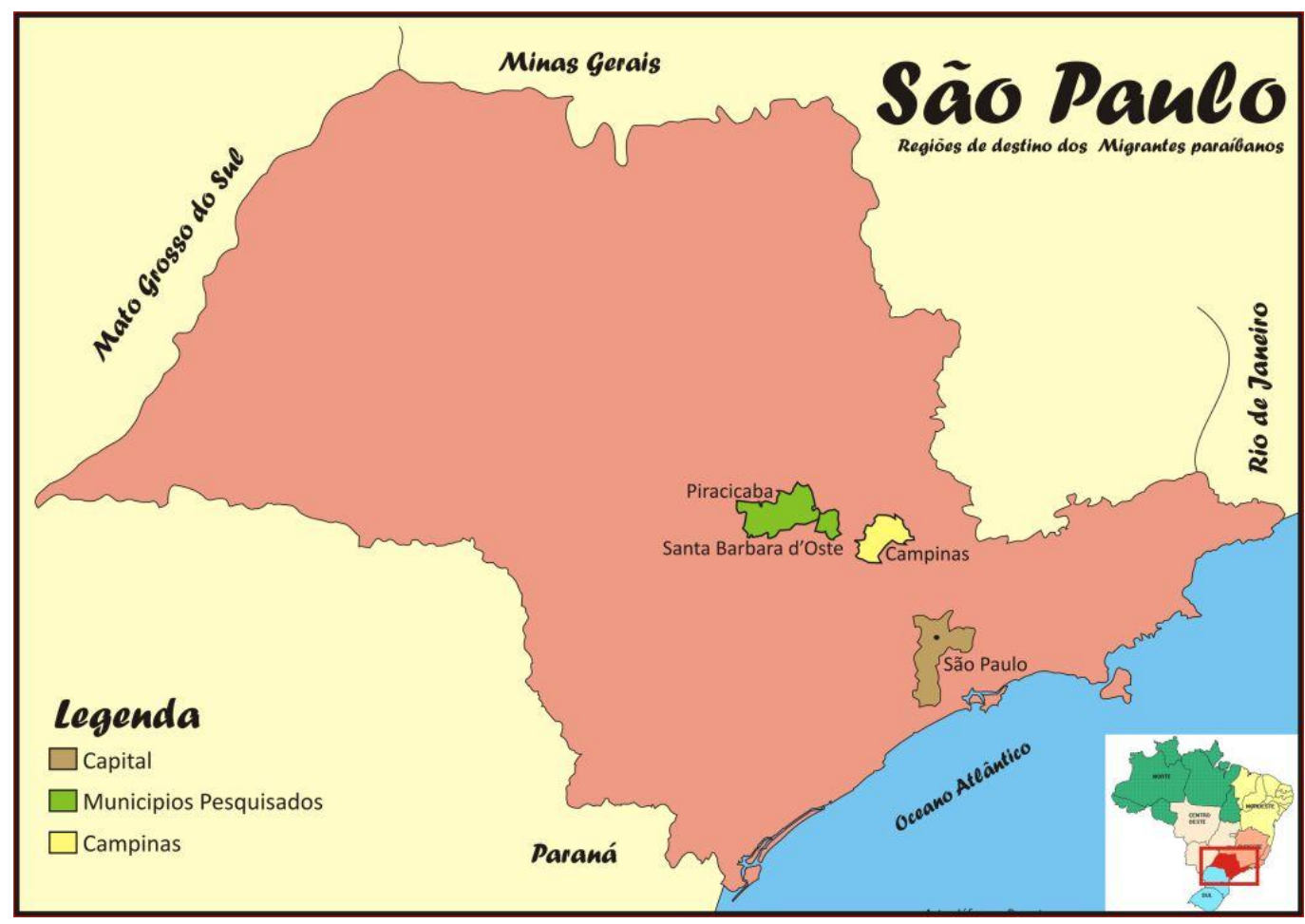

Imagem 3: Mapa de localização.

Recebido em: 30/03/2012

Aprovado em: 24/05/2012 